\title{
SADA communique to members - Licence and quality control tests for dental diagnostic X-ray imaging systems
}

SADJ November 2020, Vol. 75 No. 10 p531 - p533

\section{SADA Head Office}

Members have been receiving notification from Inspection Bodies about their $\mathrm{X}$-ray equipment being due for inspection.

On enquiry, it has been discovered that, in some instances, this notice was based on erroneous data that Inspection bodies may have received from the Radiation Control, who had not correctly updated their records, due to "a lack of manpower".

SADA strongly advises members who receive this notification to check their documentation before booking said inspections and, if the notification is incorrect, to request their usual inspection body to correct their records.

SADA has serious concerns about the current legal framework and enforcement of the Act governing X-ray equipment. It questions the Code of Practice and more particularly, the legal standing of inspection bodies, licensing delays and the entire legislative framework. To this end, SADA has made an extensive written submission to the Minister of Health raising our concerns. In the meantime, as the legislative framework applies to practitioner, in its flawed framework, we provide members useful information for the benefit of members around the whole issue of licensing and testing of X-ray equipment so that members are properly informed when receiving notices of inspections or having to licence their new or used $\mathrm{X}$-ray equipment.

\section{INTRODUCTION}

The South African Health Products Authority (SAHPRA) is the regulatory authority of South Africa responsible for the regulation of health products intended for human and animal use; amongst others, radiation emitting devices and radioactive nuclides.

The legislative mandates of SAHPRA are derived from the Constitution; the National Health Act, 2003 (Act No. 61 of 2003); the Medicines and Related Substances Act, 1965 (Act No. 101 of 1965), as amended (hereinafter referred to as "the Medicines Act"); and other relevant legislation, regulations and policies.

Further, SAHPRA's mandate has expanded to include the regulation and control of radiation emitting devices and radioactive nuclides under the Medicines Act and the Hazardous Substances Act, 1973 (Act No. 15 of 1973). The Hazardous Substances Act does not

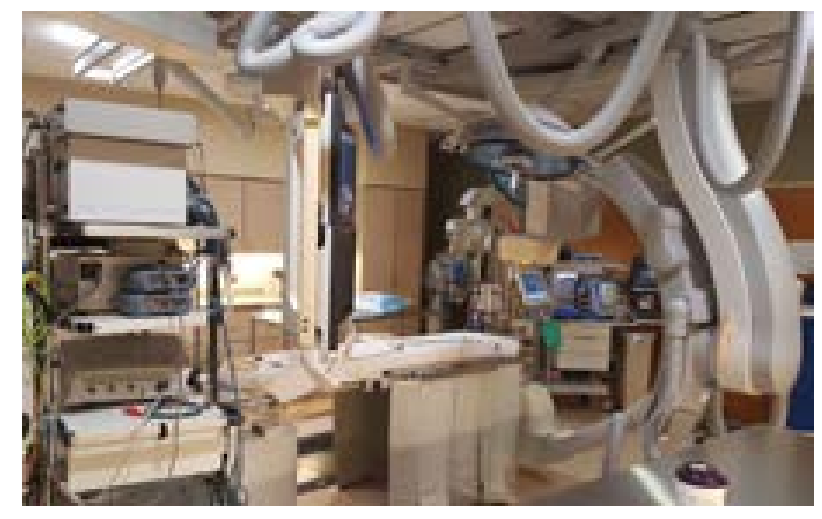

allow any person to use radiation equipment unless he/she holds a licence under the Act for that purpose.

\section{Licence}

The Regulations require that a joint product and premises licence be obtained for $X$-ray equipment before it may be installed and commissioned.

(a). Licences are not transferable and are issued: To a specific person or institution; For specific equipment and its application, and

(b). For a specific premise.

It is the responsibility of the prospective user of an $\mathrm{x}$-ray unit to be in possession of a licence from the regulator prior to installation of the unit. Practitioners may be assisted by the supplier of the equipment in this process.

(Form RC001) (01/2016) application for a licence in terms of the hazardous substances act, 1973 (Act 15 of 1973) to use an X-ray device)

https://www.sahpra.org.za/radiation-control/

\section{Pre-owned units}

The prospective user must ensure that acceptance tests are performed. Granting of a licence to use a unit is subject to submission of the results of the tests to the regulator.

When an existing licenced unit is moved to a new premise (building) or room, prior to use, acceptance tests must be performed on the unit and the results submitted to the regulator.

(Form RC001) (01/2016) application for a licence in terms of the hazardous substances act, 1973 (act 15 of 1973) to use an $\mathrm{x}$-ray device).

https://www.sahpra.org.za/radiation-control/ 


\section{New/modified premises}

The licence holder must apply for and obtain permission prior to:

(a). Modification of any licensed premises or layout of equipment on such premises, and/or

(b). Change of licensed premises (building) or equipment moved to other rooms within the same building.

(Form RC002) application in terms of article 4 of the hazardous substances act, 1973 (act 15 of 1973) disposal of a licensed electronic product and/or new/ modified premises:

https://www.sahpra.org.za/radiation-control/

\section{Acceptance and routine quality control tests}

An Inspection Body (IB) approved by the Department of Health (DoH)/ SANAS must be used to perform all the acceptance tests. The present accredited Inspection Bodies on the SAHPRA website (as at 7 March 2019) are shown in Table 1.

\section{Acceptance tests}

Acceptance tests are the initial tests performed directly after installation and before the equipment is being put into clinical service.

Acceptance tests have three purposes, namely:

(a). To ensure that the unit meets stated specifications.

(b). To establish baseline parameters for the future quality control program

(c). To familiarize the customer with operation of the unit.

\section{New units}

When a new unit is installed, acceptance tests must be performed by the supplier of the x-ray unit and the results recorded on the prescribed form and filed in the Individual Equipment Record (IER) of the unit. The IER is for example, a ring binder containing all the information as prescribed in Table 1 below for each piece of equipment.

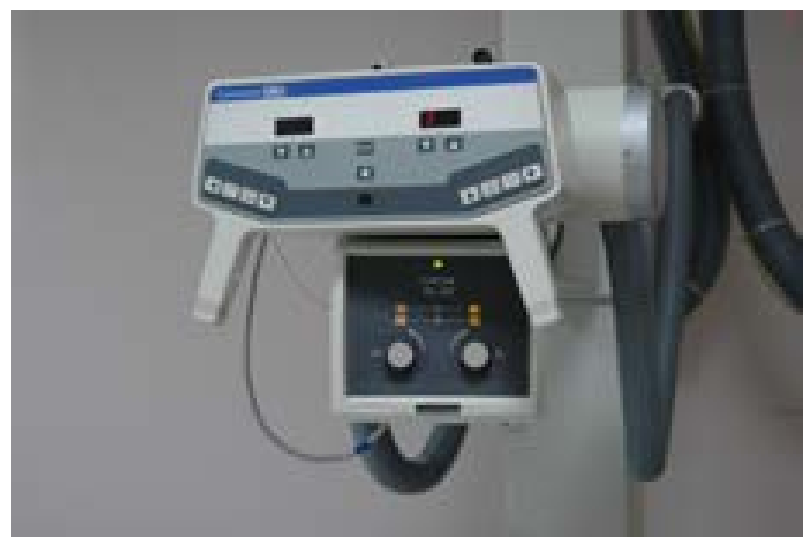

\section{Pre-owned units}

The prospective user must ensure that acceptance tests are performed. Granting of a licence to use a unit is subject to submission of the results of the tests to Radiation Control.

When an existing licenced unit is moved to a new premise (building) or room, prior to use, acceptance tests must be performed on the unit and the results submitted to Radiation Control.

\begin{tabular}{|c|c|c|c|c|}
\hline Company & Location & Contact & Tel & Email \\
\hline $\begin{array}{l}\text { Africa X-ray Industrial } \\
\text { \& Medical }\end{array}$ & Midrand & Mr Peter Wolff & $\begin{array}{l}0113140140 \\
0833807359\end{array}$ & peterw@axim.co.za \\
\hline Gendent & Durban & Mr Graham Wollentine & $\begin{array}{l}0312028690 \\
0832296380\end{array}$ & graham@gendentsa.co.za \\
\hline Millner's Dental Suppliers & $\begin{array}{l}\text { Cape Town, } \\
\text { Johannesburg }\end{array}$ & Mrs Erika Vorster & $\begin{array}{l}0860100200 \\
0115499621\end{array}$ & erika@wright-millners.co.za \\
\hline $\begin{array}{l}\text { Sirona Dental Systems } \\
\text { South Africa (Pty) Ltd }\end{array}$ & $\begin{array}{l}\text { Woodmead, } \\
\text { Johannesburg }\end{array}$ & $\begin{array}{l}\text { Bernice Muller runs the } \\
\text { department } \\
\text { NO TESTING TECHNICIAN } \\
\text { AT PRESENT TIME }\end{array}$ & $\begin{array}{l}0100012827 \\
0822156724\end{array}$ & benjamina.muller@dentsplysirona.com \\
\hline
\end{tabular}

Table 2. Quality control tests are performed at the following prescribed frequencies.

\section{Acceptance and routine tests listed in this section must be performed by an approved Inspection Body}

Extra-oral X-ray tubes with intra-oral image receptors, panoramic radiography and cephalometric radiography

Dental cone beam CT

On acceptance and 3 years

Dental cone beam CT: DAP

Film Viewing (Viewing boxes used for reporting/interpretation of medical images)

On acceptance and 12 monthly

On acceptance and 24 monthly

On acceptance and 3 years

On acceptance \& 3 years

On acceptance \& 3 years

On acceptance $\& 3$ years

CR reader

DDR system 


\section{Quality Control tests (QC)}

Some routine tests are required to be carried out by the practitioner as licence holder and others by the appointed Inspection Body (Please see II Table 2 (page 9) in CODE: DIAGNOSTIC QC DENTAL (March 2017) Version 10 link 2 below). All the quality control tests are performed at the prescribed frequencies as specified in Table 2, the frequency may also be influenced by the age, stability, make, model, etc., of the equipment.

\section{Useful contacts}

Group III hazardous substances.

Installation and use of new Group III equipment: Dental X-rays: rcdent.xrays@sahpra.org.za
Installation and use of pre-owned Group III equipment:

Gauteng, North West, Limpopo and Mpumalanga: cyril.mathiba@sahpra.org.za

Western Cape and Northern Cape: debbie.coetzee@sahpra.org.za

Kwazulu-Natal, Free State and Eastern Cape: mala.bickhoo@sahpra.org.za

\section{References}

1. https://www.sahpra.org.za/wp-content/uploads/2020/01/ Dental-Radiography-Guidelines-2.pdf.

2. https://www.sahpra.org.za/wp-content/uploads/2020/01/ DIAGNOSTIC-QC-Dental-March-2017-Version-10-2.pdf.

3. SAHPRA website: https://www.sahpra.org.za/radiationcontrol/.

\section{Do the CPD questionnaire on page 591}

The Continuous Professional Development (CPD) section provides for twenty general questions and five ethics questions. The section provides members with a valuable source of CPD points whilst also achieving the objective of CPD, to assure continuing education. The importance of continuing professional development should not be underestimated, it is a career-long obligation for practicing professionals.

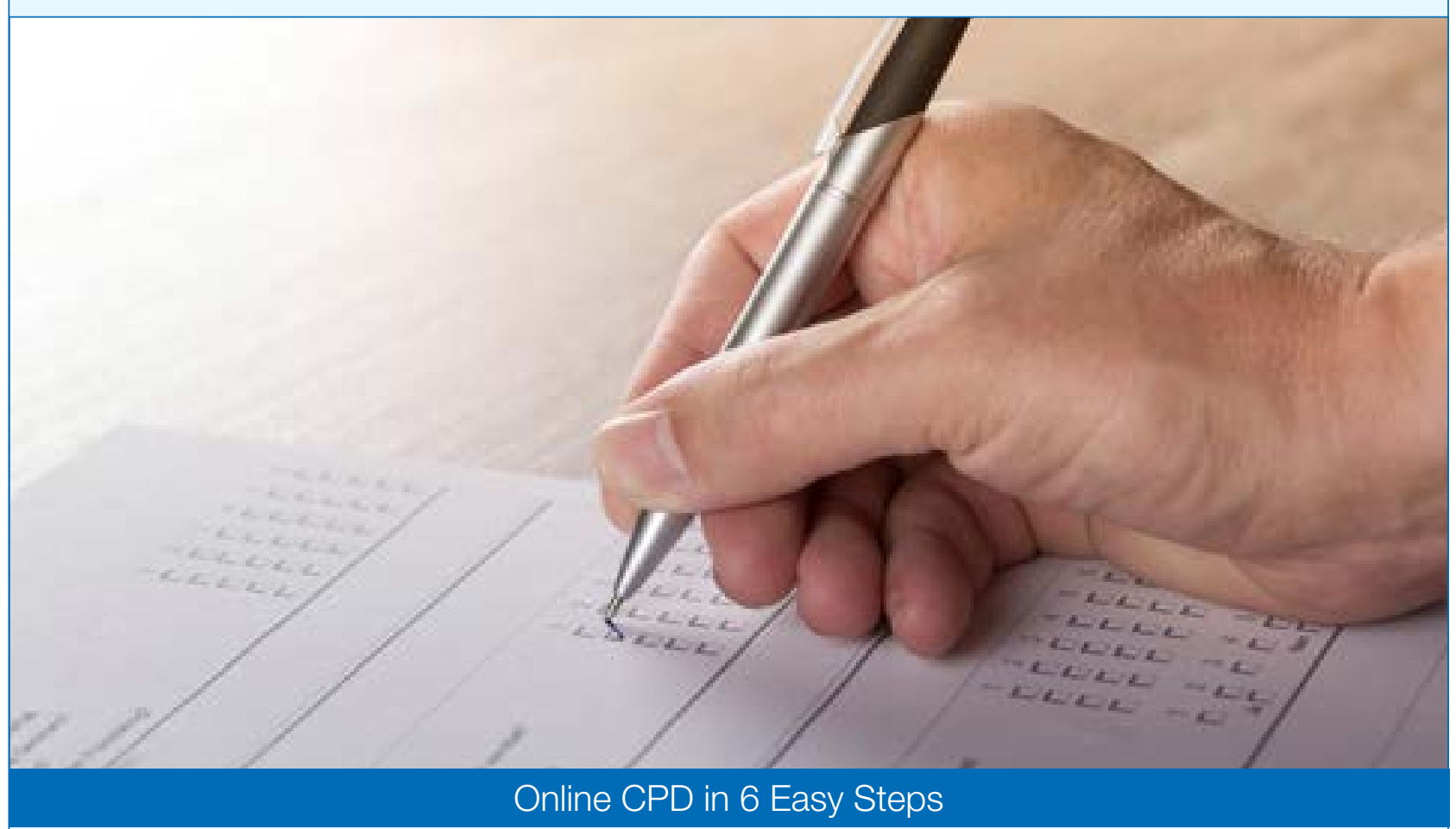

1. Go to the SADA website www.sada.co.za.

2. Log into the 'member only' section with your unique SADA username and password.

3. Select the CPD navigation tab.

4. Select the questionnaire that you wish to complete.

5. Enter your multiple choice answers. Please note that you have two attempts to obtain at least $70 \%$.

6. View and print your CPD certificate. 